\title{
Fat graft - the natural choice for reconstructive, regenerative and aesthetic surgery
}

Samir Ibrahim ${ }^{1}$, Joanna Rybacka-Mossakowska ${ }^{2}$, Sławomir Michalak ${ }^{2}$

\begin{abstract}
The search for appropriate filler, which can be used for aesthetic and reconstructive operations is currently one of challenges for plastic surgery. The application of absorbable and permanent artificial fillers may cause adverse events. Thus, autologous fat grafting can be a safe alternative. Moreover, fat tissue is rich in adipose-derived stem cells (ASC), which can be successfully used for regenerative procedures. The paper reviews reports on fat grafting procedures, which indicate risks and their possible prophylactic.

Adipose tissue is a much more prolific source of ASCs than bone marrow. Basically, ASC are characterized by a spectrum of markers: CD11b-CD45-CD13+CD73+CD90+, which can be widened by CD36+CD106-CD10+CD26+CD49d+CD49e+CD3-D49f -PODXL- to improve phenotyping. It is suggested to use at least two negative markers and two positive markers during the same phenotyping analysis. Fat transfer requires appropriate approach, planning and technique to make it clinically successful.

Fat grafting fulfills the expectations for ideal injectable agent, which can be used for aesthetic and reconstructive surgery. To improve the survival of fat graft, careful decisions on donor site, local anesthetic administration, liposuction method, processing and placement methods need to be made. Moreover, fat is the source of adipose-derived stem cells which can be used for regenerative procedures. A proper transformation and identification of those cells is required to improve clinical effects.
\end{abstract}

Running title: Fat graft - The natural choice for plastic surgery

Keywords: fat graft, liposuction, adipose -derived stem cells, regeneration

\footnotetext{
* Correspondence: sarsorah18@hotmail.com

${ }^{1}$ Mandala Beauty Clinic, Chwiałkowskiego 28, 61-553 Poznań, Poland

${ }^{2}$ Department of Neurochemistry and Neuropathology, Chair of Neurology, Poznan University of Medical Sciences, Przybyszewskiego str. 49, 60-355 Poznań, Poland

Full list of author information is available at the end of article 


\section{Introduction}

The search for the ideal material to correct soft tissues defects, has been and still is a challenging concern for surgeons. The ideal injectable agent for soft tissue augmentation must fulfill certain criteria. It must be easy to use, biocompatible, inexpensive, and non-toxic. Furthermore, such an agent should fill the tissue envelope with a natural feel and appearance for optimal cosmetic effect, and it must produce consistent and reproducible results. For years different types of implants were used in plastic and reconstructive procedures such as breast implants, buttock implants with acceptable results, but implant remain an artificial material, which causes side effects. In many cases an artificial appearance and effect was observed. The final aesthetic effect is dictated by the shape of the implants and complications, such as: rejection, infection, capsular contracture, asymmetry and folding. Recently, reports on anaplastic large cell lymphoma related to breast implants were published [1]. Fat can serve for autologous grafting, but it is also a richest source of stem cells, which, after proper identification and differentiation can be used for regenerative procedures.

\section{Artificial fillers and the adverse events of their use}

Fillers used in last five decades are categorized into absorbable (biodegradable, non-permanent) and permanent (not biodegradable) [2]. Permanent fillers (liquid silicone, paraffin, polyacrylamide hydrogel) and non-permanent (hyaluronic acid) [3] are used in the most commonly performed procedures in the cosmetic practice. As its usage is expanding, the possibility of complications is likely to increase $[4,5]$. Even in the hands of an experienced specialist, various complications can occur. The causes of side effects after administration of artificial fillers are: local reactions in injection site, inadequate technique, allergy or hypersensitivity to the filler or circulation impairment [6]. The localization of injection plays a role as well. The complications of fillers administration are categorized depending on the time of onset into early, which develop days to weeks and delayed appearing weeks to years after intervention [7]. Reactions in injection site are acute and their risk is increased by the use of anti-platelet drugs, anticoagulants, vitamin E or alcohol [8]. Moreover, HA, polyacrylamide gel, and poly-L-lactic acid can promote the growth of Staphylococcus epidermidis and cause complications related to filler contamination, particularly after multiple needle passes [9]. Unintended intramuscular injection is an example of inadequate technique of filler administration. Collagen, HA and poly-L-lactic acid can induce granulomatous response, which in some cases can be asymptomatic or manifest as er- ythema, swelling or nodule formation $[10,11,12]$. Circulation impairment caused by vascular compression and leading to necrosis or vision loss results from filler administration in the problematic regions or "danger zones" like glabella area, cheeks, nasal ala, peri-oral or temporal area $[13,14,15]$.

\section{Liposuction as the source of fat for autologous graft}

One of the most widely used plastic surgery procedures in recent years is liposuction. According to the report of American Society of Plastic Surgeons National Clearinghouse of Plastic Surgery Procedural Statistics in 2016 liposuction was on second place after breast augmentation in the ranking of 5 top plastic surgery interventions [16].

New plastic surgery techniques and technology, like fat transfer, enable more safe methods of soft tissues defects correction. Fat fulfills many of the characteristics required of a soft tissue filler. It is autologous, non-toxic, biocompatible, easily available in most patients, potentially removable and long lasting [17]. Despite the appeal of fat and widespread adoption of fat grafting in plastic and reconstructive surgery, challenges and concerns remain with this procedure. In particular, obtaining predictable, reliable, and consistent outcomes is a significant challenge and it is due to the high variability in graft volume retention. As much as 40$80 \%$ of the volume of fat injected could be lost due to necrosis or resorption [17]. The unpredictable outcome is largely attributed to the technique of fat grafting that encompasses three stages: procurement, processing, and placement of the fat.

The first 'fat grafting' procedure dates back to the late 19th century. Gustav Neuber, a German surgeon transferred in 1893, fat from the arm to the orbital region to correct scars formed from osteomyelitis [18]. Already two years later, in 1895, Viktor Czerny transferred a lipoma to the breast to establish symmetry following a unilateral partial mastectomy [19]. In 1909 Eugene Holländer used injected fat as a natural filler for the correction of face and breast deformities and described it one year later [20]. The experience of surgeons during World War I, when cartilage and fat were used for reconstructive operations in wounded soldiers, led to systematic studies, like the work of Erich Lexer [21]. The studies on the conditions required for fat graft survival were carried on in 1950's by Lyndon Peer [22]. A milestone in the development of fat grafting was systematization and standardization of techniques of fat extraction, processing, and injection by Sydney Coleman in 1990's [23,24]. Since that point, the procedure's application has significantly increased along with a wider variety of clinical applications.

Liposuction and its development nowadays offers not only a method of fat removal or body sculpting, 
but above all, it gives an access to the patient's fat as a natural and safe filler with a low rate of complications. Moreover, it is a minimally invasive procedure that does not leave scars and it is the richest source of stem cells.

Fat grafting is a process of using patient's fat from other parts of the body and filling the soft tissue defects for various purposes: aesthetic (breast and butt augmentation or face and hands rejuvenation), corrective (e.g. body asymmetries) and reconstructive (e.g. breast reconstruction after mastectomy). Furthermore, fat grafting has opened new frontiers for plastic surgeons and for other medical specialties, and have increasingly focused the attention not only due to its aesthetic capabilities, but also because of its regenerative properties.

\section{Fat tissue as the source of stem cells}

The regenerative properties of fat are due to the high content of mesenchymal stem cells (MSCs) with multilineage differentiation potential, which were identified in fat in early 2000's [25]. Adult MSCs were predominantly thought of as a bone marrow product and according to unifying theory located in the perivascular space in different tissues or organs [26]. Two fractions of cells can be obtained from adipose tissue. One is stromal vascular fraction (SVF), which is freshly isolated following enzymatic treatment and consists of heterogeneous population of cells including vascular progenitors, fibroblasts, pericytes and mesenchymal stromal cells, but also endothelial cells, erythrocytes, fibroblasts, lymphocytes, monocyte/macrophages, without mature adipocytes [27]. According to the joint statement of the International Federation for Adipose Therapeutics and Science (IFATS) and the International Society for Cellular Therapy (ISCT) [27] the optimal combination of markers for identification SVF fraction is following: CD45- ${ }^{-}$D $31^{-} \mathrm{CD} 34^{+} \mathrm{CD} 13^{+} \mathrm{CD} 73^{+}$.

A proper washing procedure and culture enables depletion of most of the hematopoietic cells present in SVF fraction and the isolation of another fraction of cells which adhere to the plastic i.e. adipose tissue-derived stromal cells (ASCs). Basically ASC are characterized by following spectrum of markers: CD11b ${ }^{-C D} 45^{-} \mathrm{CD} 13^{+} \mathrm{CD}^{2} 3^{+} \mathrm{CD} 90^{+}$which can be widened by: CD36 (GPIIIb) ${ }^{+}$and CD106 (VCAM-1)- [27 Bourin et al. 2013]. In the joint statement of IFATS and ISCT [27] it is suggested to use at least two negative markers and two positive markers during the same phenotyping analysis. Further widening of markers spectrum by: $\mathrm{CD} 10^{+} \mathrm{CD} 26^{+} \mathrm{CD} 49 \mathrm{~d}^{+} \mathrm{C}-$ D49e ${ }^{+}$CD3-D49f-PODXL(Podocalyxin) - improves phenotyping specificity [27].

As it turns out, adipose tissue is a much more prolific source of ASCs than bone marrow. The ASCs content in liposuction aspirate fraction is much greater $(10 \%)[28,29]$ than in bone marrow $(0.001 \%$ to $0.01 \%)$ [30]. Coupled with the uncom- plicated extraction of adipose tissue it opened up a new chapter for the field of regenerative medicine. Clinically, fat grafts are used to rejuvenate skin, support the restoration of tissue after radiation damage, and to treat autoimmune skin disorders. But there is a potential to use ASCs in all areas of the body, if the cells will be processed further. Adipose tissue can be processed in several ways. Fat grafting, the most basic technique, can deploy some of the regenerative powers of ASCs to injured tissue. However, not all injured areas are amenable to a 'fat graft.' In this case, isolation of ASCs from the adipose tissue has even greater potential as these cells can then be delivered intravenously or intra-arterially to places unsuitable for fat grafts. Finally, ASCs can be cultured ex-vivo in a laboratory settings to expand significantly the population of these regenerative cells.

There are many ongoing experimental animal studies and clinical trials using adipose derived MSCs to treat conditions as varied as chronic obstructive pulmonary disease (COPD) [31], pulmonary emphysema [32], congestive heart failure [33], osteoarthritis [34], diabetes [35], autism [36], Crohn's disease [37], multiple sclerosis [38], Parkinson's disease [39], macular degeneration [40] or urinary incontinence [41].

Fat transfer requires appropriate approach, planning and technique to make it clinically successful. The final effects may vary depending on the donor and the recipient site and on the surgeon (liposuction method, processing, time from harvesting to implantation, etc.). Several different lipotransfer techniques have been developed during recent years, but still there is no gold standard [17]. No clear recommendations exist about the best way to ensure maximum survival of the graft. The controversy concerns: ideal cannula to collect and inject the fat, contamination with blood, effect of injuries on fat cells, exposure of fat cells to the air, longevity and vitality of fat cells. Few groups worked on procedure standardization and indicated some key points: preferred donor sites at the low abdomen and inner thigh, lower negative pressure during liposuction for fat harvesting, careful centrifugation, which enables well tissue isolation with sufficient growth factors and ASCs yield, injection of small graft volumes and cell enriched fat transfer (CEFT) $[42,43,44]$.

Moreover, the surgical experience and literature provide support for crucial steps of fat transfer. Donor site may vary, however, usually fat is harvested from the abdomen, lateral or anterior thighs and knees, or from the lower back. Regardless of, whether there is an optimal donor site, experts suggest, that some sites may be preferable to others. Some studies have shown that lower abdominal fat contains more stem cells compared to other areas [45]. Fat survival can depend on the count of stem cells, 
which support the graft through adipogenesis and angiogenesis [46, 47]. However, other studies have not shown the effect of donor site on fat survival $[48,49]$. Different effects observed may result from the age and comorbidities, which were not taken into consideration.

Few studies related to the effects of infiltration have not shown adverse effects of local anesthetics or epinephrine on fat graft survival $[50,51]$. However, Keck et al. [52] reported moderate effect of mepivacaine and ropivacaine and severe unfavorable influence of articaine/epinephrine and lidocaine on preadipocyte viability. Thus low concentration of anesthetics or epinephrine should be preferred.

Currently a spectrum of liposuction methods is used in plastic surgery including conventional liposuction, power-assisted liposuction or manual with syringe, Coleman technique, internal ultrasound-assisted liposuction and external ultrasound-assisted liposuction [44]. It was reported that low harvest pressure $(-250 \mathrm{mmHg})$ resulted in higher adipocyte count compared to high pressure $(-750 \mathrm{mmHg})$ $[53,54]$. Until now, there is no clear evidence that any type of harvesting technique is beneficial compared to the others, however the results of national survey of the American Society of Plastic Surgeons suggest that hand-held manual suction is the preferred technique [55]. As for harvesting cannulas, larger sizes ( $\geq 4 \mathrm{~mm}$ ) may be preferable as they appear to increase adipocyte survival rate $[56,57]$.

Processing of harvested fat affects also the graft survival. It provides concentrated adipocytes, eliminates tumescent fluid, blood with hematopoietic cells, disrupted cells and free oil. Processing procedures widely used are: filtration, centrifugation and sedimentation [55]. However, there is no clear evidence for the superiority of any of these methods [44].

The final step of fat transfer is the placement of the graft. Crucial for this phase of fat transfer is to inject small aliquots of fat between layers of host tissue in uniform manner to enable well integration with surrounding and survival. The cannulas with wider-diameter $(2.5 \mathrm{~mm})$ used for fat placement improve fat graft survival compared with small-diameter cannulas [56].

\section{Elaboration of standard operating procedure for liposuction}

Samir Ibrahim elaborated standard operating procedure (SOP) currently used in Mandala Beauty Clinic after 20 years of experience with liposuction and fat grafting to different parts of the body (buttocks, breast, hands, face and to other body areas) and having the opportunity to work closely with world leaders of liposuction and fat grafting such as Luiz Toledo at Obagi hospital (Riyadh, Saudi Arabia), John A. Millard (Denever, USA), Alfredo Hoyos (Bogota, Colombia) and Yves-Gerard Illouz (France).
This SOP relies on:

1. Delicate handling during the whole process, which is of utmost importance to preserve graft integrity. Exposure to inappropriate external forces, including mechanical, chemical, or barometric, should be avoided to minimize the risk of cellular damage and necrosis. Harvested fat should be maintained as close as possible to body temperature.

2. Preoperative planning is important. A thorough medical history and patient physical examination are crucial for breast deficit evaluation. Assessment of the donor site (reconstruction may be needed in the future with donor area tissues) and prior breast surgeries affect preoperative planning. It is essential to determine the amount of fat needed for reconstruction.

3. Sterile technique. General principles of sterile technique should be monitored at all stages of the procedure.

4. Tumescent solution. In general $1 \mathrm{~mL}$ of tumescent solution is injected for every $1 \mathrm{~mL}$ of lipoaspirate. Local anesthesia is performed with $20 \mathrm{ml}$ of $1 \%$ lidocaine +1 amp. epinephrine $(1 \mathrm{mg} / 1 \mathrm{ml})$ in $0.5 \mathrm{~L}$ of $0.9 \% \mathrm{NaCl}$ solution. At least $10-15$ minutes are needed for the vasoconstrictive effects.

5. The use of 2.9, 3.6 or $4.6 \mathrm{~mm}$ cannulas depending on the donor site. The applied suction pressure is $-250 \mathrm{mmHg}$ and ultrasound Vaser Lipo device is used for liposuction.

6. Efficacious and continuous procedure. Harvest, process, and inject immediately.

7. Lipotransfer, placement of the graft is based on spread injections enabling even distribution.

To conclude, fat grafting fulfills the expectations for ideal injectable agent, which can be used for aesthetic and reconstructive surgery. To improve the survival of fat graft careful decisions on donor site, local anesthetic administration, liposuction method, processing and placement methods need to be made. Moreover, fat is the source of adipose-derived stem cells which can be used for regenerative procedures. A proper transformation and identification of those cells is required to improve clinical effects.

\section{Acknowledgements}

We do not have any acknowledgments related to this study

\section{Competing interests}

The authors declare they have no conflict of interest

\section{Author details}

Samir Ibrahim, Mandala Beauty Clinic, Chwiałkowskiego 28, 61-553 Poznań, Poland, e-mail: sarsorah18@hotmail.com

Received: 29 August 2017

Accepted: 07 September 2017

\section{References}

1. O'Neill AC, Zhong T, Hofer SOP. Implications of Breast Implant-Associated Anaplastic Large Cell Lymphoma (BIA-ALCL) for Breast Cancer Re- 
construction: An Update for Surgical Oncologists. Ann Surg Oncol. 2017; doi: 10.1245/s10434-017-6014-0.

2. Lourith N, Kanlayavattanakul M. Biopolymeric agents for skin wrinkle treatment. J Cosmet Laser Ther. 2016;18(5):301.

3. Lee SK, Kim HS. Correction of horizontal neck lines: Our preliminary experience with hyaluronic acid fillers. J Cosmet Dermatol. 2017; doi: 10.1111/jocd.12382.

4. Peters W, Fornasier V. Complications from injectable materials used for breast augmentation. Can J Plast Surg. 2009;17(3):89.

5. Lee J II, Kang SJ, Sun H. Skin Necrosis with Oculomotor Nerve Palsy Due to a Hyaluronic Acid Filler Injection. Arch Plast Surg. 2017;44:340.

6. Lafaille P, Benedetto A. Fillers: contraindications, side effects and precautions. J Cutan Aesthet Surg. 2010;3(1):16.

7. Lowe NJ, Maxwell CA, Patnaik R. Adverse reactions to dermal fillers: Review. Dermatol Surg. 2005;31:1616.

8. Duffy DM. Complications of fillers: overview. Dermatol Surg. 2005; 31(11 Pt 2):1626

9. Saththianathan M, Johani K, Taylor A, Hu H, Vickery K, Callan P, Deva AK. The Role of Bacterial Biofilm in Adverse Soft-Tissue Filler Reactions: A Combined Laboratory and Clinical Study. Plast Reconstr Surg. 2017;139(3):613.

10. Cohen JL. Understanding, avoiding, and managing dermal filler complications. Dermatol Surg. 2008;34:S92.

11. Stolman LP. Human collagen reactions. Dermatol Surg. 2005;31:1634.

12. Mest DR, Humble G. Safety and efficacy of poly-L-lactic acid injections in persons with HIV-associated lipoatrophy: the US experience. Dermato Surg. 2006;32:1336.

13. Glaisch A, Cohen J, Goldberg L. Injection necrosis of the glabella: Protocol for prevention and treatment after use of dermal fillers. Dermato Surg. 2006; 32: 276.

14. Emer J, Waldorf H. Injectable neurotoxins and fillers: There is no free lunch. Clin Dermat. 2011; 29: 678.

15. Yanyun C, Wenying W, Jipeng L, Yajie L, Lin L, Ning L. Fundus artery occlusion caused by cosmetic facial injections. Chinese Med J. 2014; 127 1434.

16. 2016 Plastic Surgery Statistics Report. www.plasticsurgery.org

17. Gir P, Brown SA, Oni G, Kashefi N, Mojallal A, Rohrich RJ. Fat grafting: evidence-based review on autologous fat harvesting, processing, reinjection, and storage. Plast Reconstr Surg. 2012;130(1):249.

18. Neuber G. Úber die Wiederanheilung vollständig vom Körper getrennter, die ganze Fettschicht enthaltender Hautstücke. Zbl f Chir. 1893;30:16.

19. Czerny V. Drei plastische Operationen. III. Plastischer Ersatz der Brustdrüse durch ein Lipom. Arch F Klin Chir. 1895;50:544.

20. Holländer E. Über einen Fall von fortschreitenden Schwund des Fettgewebes und seinen kosmetischen Ersatz durch Menschenfett. Münch Med Wochenschr. 1910;57:1794.

21. Lexer E. Die freien Transplantationen. Stuttgart (Germany):Enke; 1919-1924.

22. Peer LA. Transplantation of tissues. Baltimore (MD): Williams \& Wilkins; 1955.

23. Coleman SR. The technique of periorbital lipoinfiltration. Oper Techn Plast Surg. 1994;1:120.

24. Coleman SR. Long-term survival of fat transplants: controlled demonstrations. Aesthetic Plast Surg. 1995;19:421.

25. Zuk PA, Zhu M, Mizuno H, Huang J, Futrell JW, Katz AJ et al. Multilineage cells from human adipose tissue: implications for cellbased therapies. Tissue Eng. 2001;7(2):211.

26. Crisan M, Yap S, Casteilla L, Chen CW, Corselli M, Park TS. et al. A perivascular origin for mesenchymal stem cells in multiple human organs. Cell Stem Cell. 2008;3(3):301.

27. Bourin P, Bunnell BA, Casteilla L, Dominici M, Katz AJ, March KL et al Stromal cells from the adipose tissue-derived stromal vascular fraction and culture expanded adipose tissuederived stromal/stem cells: a joint statement of the International Federation for Adipose Therapeutics and Science (IFATS) and the International Society for Cellular Therapy (ISCT). Cytotherapy. 2013; 15(6):641.

28. Aust L, Devlin B, Foster SJ, Halvorsen YD, Hicok K, du Laney T et al. Yield of human adipose-derived adult stem cells from liposuction aspirates. Cytotherapy. 2004;6:7.

29. Zhu Y, Liu T, Song K, Fan X, Ma X, Cui Z. Adipose-derived stem cell: a better stem cell than BMSC. Cell Biochem Funct 2008;26:664.

30. Pittenger MF, Mackay AM, Beck SC, Jaiswal RK, Douglas R, Mosca JD et al. Multilineage potential of adult human mesenchymal stem cells. Science 1999;284:143.

31. Katsha AM, Ohkouchi S, Xin H, Kanehira M, Sun R, Nukiwa T et al. Paracrine factors of multipotent stromal cells ameliorate lung injury in an elastase-induced emphysema model. Mol Ther. 2011;19(1):196.
32. Shigemura N, Okumura M, Mizuno S, Imanishi Y, Nakamura T, Sawa Y Autologous transplantation of adipose tissue-derived stromal cells ameliorates pulmonary emphysema. Am J Transplant. 2006;6(11):2592.

33. Palpant NJ, Metzger JM. Aesthetic Cardiology: Adipose-Derived Stem Cells for Myocardial Repair. Curr Stem Cell Res Ther. 2010;5(2):145.

34. Cui G-H, Wang YY, Li Ch-J, Shi Ch-H, Wang W-S. Efficacy of mesenchymal stem cells in treating patients with osteoarthritis of the knee: A meta-analysis. Exp Ther Med. 2016;12(5):3390.

35. Paek HJ, Kim C, Williams SK. Adipose stem cell-based regenerative medicine for reversal of diabetic hyperglycemia. World J Diabetes. 2014;5(3):235.

36. Siniscalco D, Bradstreet JJ, Sych N, Antonucci N. Mesenchymal stem cells in treating autism: Novel insights. World J Stem Cells. 2014;6(2):173.

37. Panes J. Stem Cell Therapy for Perianal Fistulas in Crohn's Disease. Gastroenterol Hepatol (N Y). 2016;12(10):637.

38. Stepien A, Dabrowska NL, Maciagowska M, Piusinska-Macoch R, Zolocinska A, Mazur S, et al. Clinical Application of Autologous Adipose Stem Cells in Patients with Multiple Sclerosis: Preliminary Results. Mediators Inflamm. 2016;2016:5302120.

39. Choi HS, Kim HJ, Oh JH, Park HG, Ra JC, Chang KA et al. Therapeutic potentials of human adipose-derived stem cells on the mouse model of Parkinson's disease. Neurobiol Aging. 2015;36(10):2885.

40. Mead B, Berry M, Logan A, Scott RA, Leadbeater W, Scheven BA. Stem cell treatment of degenerative eye disease. Stem Cell Res. 2015;14(3):243.

41. Lin G, Wang G, Banie L, Ning H, Shindel AW, Fandel TM et al. Treatment of Stress Urinary Incontinence with Adipose Tissue-Derived Stem Cells Cytotherapy. 2010;12(1):88.

42. Lin JY, Wang C, Pu LL. Can we standardize the techniques for fat grafting? Clin Plast Surg. 2015;42(2):99.

43. Cohen SR. Fat Grafting in the Face: Standardization of Harvest, Processing, Cell Enrichment and a New Facial Component Analysis Scale. Plastic Reconstr Surg. 2011; 128(4S): 8.

44. Gabriel A, Champaneria MC, Maxwell GP. Fat grafting and breast reconstruction: tips for ensuring predictability. Gland Surg. 2015;4(3):232.

45. Padoin AV, Braga-Silva J, Martins P, Rezende K, Rezende AR, Grechi B et al. Sources of processed lipoaspirate cells: influence of donor site on cell concentration. Plast Reconstr Surg. 2008;122:614.

46. Matsumoto $\mathrm{D}$, Sato $\mathrm{K}$, Gonda $\mathrm{K}$, Takaki $\mathrm{Y}$, Shigeura $\mathrm{T}$, Sato $\mathrm{T}$ et al. Cell-assisted lipotransfer: supportive use of human adipose-derived cells for soft tissue augmentation with lipoinjection. Tissue Eng. 2006;12(12):3375.

47. Yoshimura K, Suga H, Eto H. Adipose-derived stem/ progenitor cells: roles in adipose tissue remodeling and potential use for soft tissue augmentation. Regen Med. 2009;4:265.

48. Rohrich RJ, Sorokin ES, Brown SA. In search of improved fat transfer viability: a quantitative analysis of the role of centrifugation and harvest site. Plast Reconstr Surg. 2004; 113(1):391.

49. Small K, Choi M, Petruolo O, Lee C, Karp N. Is there an ideal donor site of fat for secondary breast reconstruction? Aesthet Surg J. 2014;34(4):545.

50. Moore JH Jr, Kolaczynski JW, Morales LM, Considine RV, Pietrzkowski Z, Noto PF et al. Viability of fat obtained by syringe suction lipectomy: effects of local anesthesia with lidocaine. Aesthetic Plast Surg. 1995;19(4):335

51. Kim IH, Yang JD, Lee DG, Chung HY, Cho BC. Evaluation of centrifugation technique and effect of epinephrine on fat cell viability in autologous fat injection. Aesthet Surg J. 2009; 29(1):35.

52. Keck M, Zeyda M, Gollinger K, Burjak S, Kamolz LP, Frey M et al. Local anesthetics have a major impact on viability of preadipocytes and their differentiation into adipocytes. Plast Reconstr Surg. 2010;126(5):1500.

53. Khouri RK, Rigotti G, Cardoso E, Khouri RK Jr, Biggs TM. Megavolume autologous fat transfer: part II. Practice and techniques. Plast Reconstr Surg. 2014;133:1369.

54. Cheriyan T, Kao HK, Qiao X, Guo L. Low harvest pressure enhances autologous fat graft viability. Plast Reconstr Surg. 2014; 133(6):1365.

55. Kling RE, Mehrara BJ, Pusic AL, Young VL, Hume KM, Crotty CA et al. Trends in autologous fat grafting to the breast: a national survey of the american society of plastic surgeons. Plast Reconstr Surg. 2013;132(1):35

56. Ozsoy Z, Kul Z, Bilir A. The role of cannula diameter in improved adipocyte viability: a quantitative analysis. Aesthet Surg J. 2006;26(3):287.

57. Erdim M, Tezel E, Numanoglu A, Sav A. The effects of the size of liposuction cannula on adipocyte survival and the optimum temperature for fat graft storage: an experimental study. J Plast Reconstr Aesthet Surg. 2009;62(9):1210. 